\title{
Vegetative Propagation of Gabirobeira Associate to Indolbutyric Acid in Different Seasons
}

\author{
Lasara K. F. Souza ${ }^{1}$, Lana L. L. Dias ${ }^{1}$, Moab A. Barbosa ${ }^{1}$, Diego I. Rocha ${ }^{1}$, Edésio F. Reis ${ }^{1}$, \\ Francielly R. Gomes ${ }^{1}$, Pedro H. M. de Souza ${ }^{1}$, Marcelo M. Costa ${ }^{1}$, Luciana C. Carneiro ${ }^{1}$, Simério C. S. Cruz ${ }^{1}$, \\ João A. A. Oliveira ${ }^{2}$, Alejandro H. Salazar ${ }^{3} \&$ Danielle F. P. Silva ${ }^{1}$ \\ ${ }^{1}$ Federal University of Goiás, Goiás, Brazil \\ ${ }^{2}$ Federal University of Viçosa, Viçosa, Brazil \\ ${ }^{3}$ University of Caldas, Manizales, Colombia \\ Correspondence: Lasara K. F. Souza, Federal University of Goiás, Cidade Universitária José Cruciano de Araújo \\ (Jatobá), Rod BR 364 KM 192-Parque Industrial, 3800, CEP 75801-615, Jataí, Goiás, Brazil. E-mail: \\ engekah.lk@gmail.com
}

Received: January 28, 2019

Accepted: April 13, 2019 Online Published: May 31, 2019

doi:10.5539/jas.v11n7p187

URL: https://doi.org/10.5539/jas.v11n7p187

\begin{abstract}
The propagation of gabirobeira is carried out by seeds. However, the recalcitrance and not tolerance of the seeds to the storage compromise the formation of seedlings. Thus, the propagation by cuttings can be an option, being able to provide significant results in different seasons. The objective of this work was to evaluate the vegetative propagation by stem cuttings of two species of gabirobeira (Campomanesia adamantium and Campomanesia pubescens) associate to indolbutyric acid (IBA) at differents seasons of the year. Cuttings of the two species were obtained in the 4 seasons and concentrations of $0,2000,4000,6000$ and $8000 \mathrm{mg} \mathrm{L}^{-1}$ of IBA were used, by immersion in the solution for 15 seconds and sequentially staked on trays containing a sand substrate. Sixty days after experiments were set it was evaluated the percentage of cuttings with shoots, live cuttings, dead cuttings, cuttings with calluses and rooted cuttings. A completely randomized design with 5 treatments, 4 replicates and 8 cuttings per plot was adopted. During the whole experiment, the greenhouse, substrate and cutting leaves temperature was monitored. The use of IBA did not promote adventitious rhizogenesis, but provided a high percentage of survival for the species Campomanesia adamantium and Campomanesia pubescens by stem cuttings during the spring season.
\end{abstract}

Keywords: Campomanesia, cutting, rooting, Savanna

\section{Introduction}

Fruits species of gabirobeira belongs to genus Campomanesia and can be found in several states of Brazil, especially in the state of Goiás, recognized for its high productive potential (A. M. Alves, M. S. O. Alves, Fernandes, R. V. Naves, \& M. M. V. Naves, 2013). However, such species is not commercially explored due to the absence of commercial plantations, lack of domestication, with use restricted to domestic orchards, making it difficult to obtain information on propagation and cultivation techniques (Santos, Reis, Pinto, \& Silva, 2018).

Sexual propagation has still been the main method used. However, it has resulted in the formation of individuals with high genetic variability, hindering the formation of homogeneous orchards, in addition, seeds are recalcitrance and little tolerant to long periods of storage, which compromises the formation of new seedlings (Martins, Mantelli, Santos, Costa-Netto, \& Pinto, 2015).

Propagation through stem cuttings may represent a low cost alternative and also a way to obtain uniformity among plants (Fragoso et al., 2017a). This technique is feasible for most fruit species; but differentiated responses may occur according to the quality of the biological material, and endogenous and exogenous factors, as well as the time of the year in which propagules are collected (Véras et al., 2018).

The season the cuttings are collected has a decisive impact in the rhizogenic process. For species of easy rooting, the seasons may not influence responses, while in certain species due to the physiological and environmental factors, rooting can occur in a specific time of the year (Zem, Weiser, Zuffellato-Ribas, \& Radomski, 2015). 
High temperatures may coincide with increased metabolic activities favoring sprouting, increased growth rate and cuttings development (Mendonça, Batista, Magalhães, Pereira, \& Bucher, 2018).

Auxin exogenous application can promote rhizogenic induction, growth regulators, like IBA, stimulate cell division, cell elongation and metabolic activity right where incision is made. Indolbutyric acid (IBA) is more frequently used because of its greater stability, local action and reduced sensitivity to biological degradation (Gilani et al., 2018; C. Hossel, J. S. A. Hossel, \& Junior, 2017).

Martins et al. (2015) evaluated the propagation of Campomanesia adamantium herbaceous and woody cuttings supplemented at concentrations of IBA $\left(0 ; 1000\right.$ and $\left.2000 \mathrm{mg} \mathrm{L}^{-1}\right)$ immersed for 10 seconds in the solution during December, February and May, and obtained just the formation of shoots and high percentage of woody cuttings in May.

Conversely, Pereira et al. (2017) observed just the occurrence of buds when Campomanesia adamantium and Campomanesia pubescens cuttings received IBA treatment $\left(0,800,1600\right.$ and $\left.3200 \mathrm{mg} \mathrm{L}^{-1}\right)$ by the immersion of cuttings for 15 seconds in solution during autumn. Considering the potential of the species those authors recommended new studies on other seasons and with different concentrations of indolbutyric acid.

Technical information on vegetative propagation of gabirobeira is still incipient. Considering the responses obtained in different seasons and the yield potential of these species, this study aims to evaluate the vegetative propagation of two species of gabirobeira associated to the use of indolbutyric acid (IBA) in different seasons of the year.

\section{Materials and Method}

Cuttings of Campomanesia adamantium and Campomanesia pubescens were used in different experiments, carried out in four seasons (spring, summer, autumn and winter) collected in plants belonging to the ex situ biological collection contained in the field of evaluation and conservation of resources genetics. Within this collection, seed originated plants was used and the cuttings were not standardized for physiological maturity due to the available biological material.

The collection was done manually with the aid of pruning shears, after the collection the branches were packed in plastic buckets containing water slide, and kept in the shade so that no dehydration and oxidation occurred at the base of the branches. Subsequently, these were taken to the greenhouse and kept under irrigation so that there was no dehydration of the leaves during the period of preparation of the cuttings.

Seasons of the year in which the collection and evaluation took place:

- $\quad$ Autumn (April 27, 2017-June 25, 2017);

- Winter (August 12, 2017-October 12, 2017);

- $\quad$ Spring (October 14, 2017-December 14, 2017);

- $\quad$ Summer (March 03, 2018-May 04, 2018).

Cuttings were standardized in $15 \mathrm{~cm}$ sizes and the average diameter of the cuttings used for $C$. adamantium and C. pubescens in the different seasons were obtained with the aid of a digital pachymeter with a precision of 0.01 $\mathrm{mm}$ (Table 1).

Table 1. Average data of diameter $(\mathrm{mm})$ of the gabirobeira cuttings of the two species used in the different seasons evaluated

\begin{tabular}{lll}
\hline & Campomanesia adamantium & Campomanesia pubescens \\
\hline Autumn & $9.10 \pm 0.95$ & $8.72 \pm 2.15$ \\
Winter & $7.50 \pm 2.50$ & $6.50 \pm 2.00$ \\
Spring & $5.31 \pm 2.05$ & $7.35 \pm 1.49$ \\
Summer & $7.46 \pm 2.29$ & $7.43 \pm 2.12$ \\
\hline
\end{tabular}

Bevel cuts were made at the cuttings base, in order to expose vascular cambium for greater contact with the phytoregulator. At the apex, transverse cuts were made, and a pair of leaves was kept with the surface reduced in half so that there was no excess in the foliate perspiration. Cuttings were then immersed in hydroalcoholic IBA solution at 2000, 4000, 6000 and $8000 \mathrm{mg} \mathrm{L}^{-1}$ concentrations for 15 seconds. In the control treatment there was no addition of IBA and immersion was done in distilled water. 
After IBA treatment, cuttings were immediately planted in styrofoam trays $(66 \times 34 \times 6 \mathrm{~cm})$, with perforated bases with capacity for 128 cells containing washed sand substrate.

Trays were kept under intermittent misting for 1 minute at 60 minute intervals only operated in the daytime period (6:00 a.m. to 6:00 p.m.). The greenhouse had a low density polyethylene coating and antiofidic screen. During the whole experimental period the temperature was monitored in the substrate, greenhouse and in the leaves (Table 2), data were collected with the aid of an InfraRed Thermometer-ICEL TD 961.

Leaf fertilization was aplied after 15 days each experiment was set, with the use $5 \%$ of the leaf fertilizer Niphokam (10-08-08), on the dose of of $25 \mathrm{~mL} / 5 \mathrm{~L}$

The experimental design was the completely randomized, with four replications, five treatments and eight cuttings per plot, totaling 160 for both species, C. adamantium and C. pubescens per experimental evaluation season.

After 60 days of planting, the following parameters were evaluated: number of shoots, number of live cuttings, number of dead cuttings, number of cuttings with calluses and number of rooted cuttings.

For normal distribution, data was transformed into percentage by the $\arcsin \sqrt{(\mathrm{x} / 100)}$ equation after Shapiro-Wilk test $(\mathrm{p}<0.05)$ and subsequently the analysis of variance was performed. The effects IBA concentrations and their respective means were compared by Tukey test at $5 \%$ of probability. Data analyzes were performed with the aid of statistical software Sisvar (Ferreira, 2011).

Table 2. Temperature $\left({ }^{\circ} \mathrm{C}\right)$ of the substrate, greenhouse and leaves of the gabirobeira cuttings, during the different seasons of the year

\begin{tabular}{llll}
\hline & Substrate & Greenhouse & Leaves \\
\hline Autumn & & & \\
Maximum & 32.35 & 31.58 & 29.15 \\
Minimum & 11.40 & 17.43 & 16.28 \\
Mean & 21.88 & 24.51 & 22.72 \\
Deviation & 4.68 & 4.95 & 4.77 \\
\hline Winter & & & \\
Maximum & 35.48 & 40.70 & 35.70 \\
Minimum & 13.00 & 14.65 & 9.83 \\
Mean & 24.24 & 27.68 & 22.77 \\
Deviation & 4.92 & 5.26 & 4.77 \\
\hline Spring & & & 39.52 \\
Maximum & 38.04 & 41.78 & 18.30 \\
Minimum & 18.06 & 17.40 & 28.91 \\
Mean & 28.05 & 29.59 & 5.38 \\
Deviation & 5.30 & 5.44 & 39.85 \\
Summer & & & 15.70 \\
Maximum & 42.60 & 40.30 & 27.84 \\
Minimum & 16.98 & 14.84 & 4.21 \\
Mean & 28.08 & 28.68 &
\end{tabular}

\section{Results}

Data analysis showed that in autumn, winter and summer there was no statistical difference between IBA concentrations used, percentage of cuttings with shoots, percentage of live cuttings, percentage of dead cuttings, percentage of cuttings with callus and percentage cuttings rooted for Campomanesia adamantium and Campomanesia pubescens (Tables 3 and 4). 
Table 3. Percentage of cuttings with shoots (S\%), live cuttings (L\%), dead cuttings (D\%), cuttings with calluses $(\mathrm{C} \%)$ and rooted cuttings $(\mathrm{R} \%)$ for Campomanesia adamantium submitted to IBA concentrations at different seasons.

\begin{tabular}{|c|c|c|c|c|c|}
\hline $\mathrm{IBA} \mathrm{mg} \mathrm{L}^{-1}$ & $\mathrm{~S}$ & $\mathrm{~L}$ & $\mathrm{D}$ & $\mathrm{C}$ & $\mathrm{R}$ \\
\hline \multicolumn{6}{|l|}{ Autumn (\%) } \\
\hline 0 & $12.50 \mathrm{a}$ & $12.50 \mathrm{a}$ & $87.50 \mathrm{a}$ & $0.00 \mathrm{a}$ & $0.00 \mathrm{a}$ \\
\hline 2000 & $6.25 \mathrm{a}$ & $6.25 \mathrm{a}$ & $93.75 \mathrm{a}$ & $3.13 \mathrm{a}$ & $0.00 \mathrm{a}$ \\
\hline 4000 & $0.00 \mathrm{a}$ & $0.00 \mathrm{a}$ & $100.00 \mathrm{a}$ & $0.00 \mathrm{a}$ & $0.00 \mathrm{a}$ \\
\hline 6000 & $12.50 \mathrm{a}$ & $12.50 \mathrm{a}$ & $87.50 \mathrm{a}$ & $0.00 \mathrm{a}$ & $0.00 \mathrm{a}$ \\
\hline 8000 & $6.25 \mathrm{a}$ & $6.25 \mathrm{a}$ & $93.75 \mathrm{a}$ & $0.00 \mathrm{a}$ & $0.00 \mathrm{a}$ \\
\hline CV (\%) & 84.34 & 84.34 & 6.77 & 52.75 & 0.00 \\
\hline \multicolumn{6}{|l|}{ Winter (\%) } \\
\hline 0 & $0.00 \mathrm{a}$ & $18.75 \mathrm{a}$ & $78.13 \mathrm{a}$ & $0.00 \mathrm{a}$ & $0.00 \mathrm{a}$ \\
\hline 2000 & $0.00 \mathrm{a}$ & $15.63 \mathrm{a}$ & $27.00 \mathrm{a}$ & $0.00 \mathrm{a}$ & $0.00 \mathrm{a}$ \\
\hline 4000 & $0.00 \mathrm{a}$ & $12.50 \mathrm{a}$ & $87.50 \mathrm{a}$ & $0.00 \mathrm{a}$ & $0.00 \mathrm{a}$ \\
\hline 6000 & $0.00 \mathrm{a}$ & $12.50 \mathrm{a}$ & $87.50 \mathrm{a}$ & $0.00 \mathrm{a}$ & $0.00 \mathrm{a}$ \\
\hline 8000 & $0.00 \mathrm{a}$ & $3.13 \mathrm{a}$ & $96.88 \mathrm{a}$ & $0.00 \mathrm{a}$ & $0.00 \mathrm{a}$ \\
\hline CV $(\%)$ & 0.00 & 49.51 & 6.05 & 0.00 & 0.00 \\
\hline \multicolumn{6}{|l|}{ Spring (\%) } \\
\hline 0 & $3.13 \mathrm{a}$ & $75.00 \mathrm{a}$ & $25.00 \mathrm{a}$ & $3.13 \mathrm{a}$ & $0.00 \mathrm{a}$ \\
\hline 2000 & $0.00 \mathrm{a}$ & $53.13 \mathrm{ab}$ & $46.88 \mathrm{ab}$ & $3.13 \mathrm{a}$ & $0.00 \mathrm{a}$ \\
\hline 4000 & $0.00 \mathrm{a}$ & $56.25 \mathrm{ab}$ & $43.75 \mathrm{ab}$ & $0.00 \mathrm{a}$ & $0.00 \mathrm{a}$ \\
\hline 6000 & $0.00 \mathrm{a}$ & $50.00 \mathrm{ab}$ & $50.00 \mathrm{ab}$ & $3.13 \mathrm{a}$ & $0.00 \mathrm{a}$ \\
\hline 8000 & $0.00 \mathrm{a}$ & $37.50 \mathrm{~b}$ & $62.50 \mathrm{~b}$ & $3.13 \mathrm{a}$ & $0.00 \mathrm{a}$ \\
\hline CV (\%) & 52.75 & 15.20 & 17.67 & 77.92 & 0.00 \\
\hline \multicolumn{6}{|l|}{ Summer $(\%)$} \\
\hline 0 & $6.25 \mathrm{a}$ & $34.38 \mathrm{a}$ & $65.63 \mathrm{a}$ & $6.25 \mathrm{a}$ & $3.13 \mathrm{a}$ \\
\hline 2000 & $3.13 \mathrm{a}$ & $31.25 \mathrm{a}$ & $68.75 \mathrm{a}$ & $28.13 \mathrm{a}$ & $0.00 \mathrm{a}$ \\
\hline 4000 & $3.13 \mathrm{a}$ & $43.75 \mathrm{a}$ & $56.25 \mathrm{a}$ & $18.75 \mathrm{a}$ & $0.00 \mathrm{a}$ \\
\hline 6000 & $3.13 \mathrm{a}$ & $34.38 \mathrm{a}$ & $96.88 \mathrm{a}$ & $9.38 \mathrm{a}$ & $0.00 \mathrm{a}$ \\
\hline 8000 & $6.25 \mathrm{a}$ & $31.25 \mathrm{a}$ & $68.75 \mathrm{a}$ & $9.38 \mathrm{a}$ & $0.00 \mathrm{a}$ \\
\hline CV (\%) & 73.53 & 22.06 & 12.10 & 41.23 & 52.75 \\
\hline
\end{tabular}

Note. Means followed by the same lowercase letter in the column, for each season of the year do not differ significantly from each other by the Tukey test at 5\% probability. CV (\%): Coefficient of variation. 
Table 4. Percentage of cuttings with shoots (S\%), live cuttings (L\%), dead cuttings (D\%), cuttings with calluses $(\mathrm{C} \%)$ and rooted cuttings (R\%) for Campomanesia pubescens submitted to IBA concentrations at different seasons.

\begin{tabular}{|c|c|c|c|c|c|}
\hline IBA mg L $^{-1}$ & $\mathrm{~S}$ & $\mathrm{~L}$ & $\mathrm{D}$ & $\mathrm{C}$ & $\mathrm{R}$ \\
\hline \multicolumn{6}{|l|}{ Autumn (\%) } \\
\hline 0 & $6.25 \mathrm{a}$ & $6.25 \mathrm{a}$ & $93.75 \mathrm{a}$ & $3.13 \mathrm{a}$ & $0.00 \mathrm{a}$ \\
\hline 2000 & $15.63 \mathrm{a}$ & $15.63 \mathrm{a}$ & $84.38 \mathrm{a}$ & $0.00 \mathrm{a}$ & $0.00 \mathrm{a}$ \\
\hline 4000 & $6.25 \mathrm{a}$ & $6.25 \mathrm{a}$ & $93.75 \mathrm{a}$ & $0.00 \mathrm{a}$ & $0.00 \mathrm{a}$ \\
\hline 6000 & $9.38 \mathrm{a}$ & $9.38 \mathrm{a}$ & $90.63 \mathrm{a}$ & $0.00 \mathrm{a}$ & $0.00 \mathrm{a}$ \\
\hline 8000 & $6.25 \mathrm{a}$ & $6.25 \mathrm{a}$ & $93.75 \mathrm{a}$ & $0.00 \mathrm{a}$ & $0.00 \mathrm{a}$ \\
\hline CV $(\%)$ & 65.49 & 65.49 & 5.89 & 52.75 & 0.00 \\
\hline \multicolumn{6}{|l|}{ Winter $(\%)$} \\
\hline 0 & $0.00 \mathrm{a}$ & $15.63 \mathrm{a}$ & $84.38 \mathrm{a}$ & $0.00 \mathrm{a}$ & $0.00 \mathrm{a}$ \\
\hline 2000 & $0.00 \mathrm{a}$ & $9.38 \mathrm{a}$ & $90.63 \mathrm{a}$ & $0.00 \mathrm{a}$ & $0.00 \mathrm{a}$ \\
\hline 4000 & $0.00 \mathrm{a}$ & $15.00 \mathrm{a}$ & $53.13 \mathrm{a}$ & $6.25 \mathrm{a}$ & $0.00 \mathrm{a}$ \\
\hline 6000 & $0.00 \mathrm{a}$ & $21.88 \mathrm{a}$ & $25.00 \mathrm{a}$ & $0.00 \mathrm{a}$ & $0.00 \mathrm{a}$ \\
\hline 8000 & $0.00 \mathrm{a}$ & $15.63 \mathrm{a}$ & $84.38 \mathrm{a}$ & $6.25 \mathrm{a}$ & $0.00 \mathrm{a}$ \\
\hline $\mathrm{CV}(\%)$ & 0.00 & 48.60 & 15.10 & 63.62 & 0.00 \\
\hline \multicolumn{6}{|l|}{ Spring (\%) } \\
\hline 0 & $0.00 \mathrm{a}$ & $46.88 \mathrm{ab}$ & $53.13 \mathrm{ab}$ & $3.13 \mathrm{a}$ & $0.00 \mathrm{a}$ \\
\hline 2000 & $0.00 \mathrm{a}$ & $59.38 \mathrm{a}$ & $40.63 \mathrm{a}$ & $0.00 \mathrm{a}$ & $0.00 \mathrm{a}$ \\
\hline 4000 & $0.00 \mathrm{a}$ & $37.50 \mathrm{~b}$ & $62.50 \mathrm{~b}$ & $0.00 \mathrm{a}$ & $0.00 \mathrm{a}$ \\
\hline 6000 & $0.00 \mathrm{a}$ & $25.00 \mathrm{~b}$ & $75.00 \mathrm{~b}$ & $0.00 \mathrm{a}$ & $0.00 \mathrm{a}$ \\
\hline 8000 & $6.25 \mathrm{a}$ & $25.00 \mathrm{~b}$ & $75.00 \mathrm{~b}$ & $3.13 \mathrm{a}$ & $0.00 \mathrm{a}$ \\
\hline $\mathrm{CV}(\%)$ & 54.48 & 12.68 & 8.88 & 62.70 & 0.00 \\
\hline \multicolumn{6}{|l|}{ Summer $(\%)$} \\
\hline 0 & $12.50 \mathrm{a}$ & $34.38 \mathrm{a}$ & $65.63 \mathrm{a}$ & $3.13 \mathrm{a}$ & $0.00 \mathrm{a}$ \\
\hline 2000 & $12.50 \mathrm{a}$ & $28.13 \mathrm{a}$ & $71.88 \mathrm{a}$ & $6.25 \mathrm{a}$ & $0.00 \mathrm{a}$ \\
\hline 4000 & $12.50 \mathrm{a}$ & $25.00 \mathrm{a}$ & $75.00 \mathrm{a}$ & $6.25 \mathrm{a}$ & $0.00 \mathrm{a}$ \\
\hline 6000 & $3.13 \mathrm{a}$ & $25.00 \mathrm{a}$ & $75.00 \mathrm{a}$ & $9.38 \mathrm{a}$ & $0.00 \mathrm{a}$ \\
\hline 8000 & $15.63 \mathrm{a}$ & $28.13 \mathrm{a}$ & $71.88 \mathrm{a}$ & $3.13 \mathrm{a}$ & $0.00 \mathrm{a}$ \\
\hline CV (\%) & 47.17 & 20.83 & 8.89 & 64.60 & 0.00 \\
\hline
\end{tabular}

Note. Means followed by the same lowercase letter in the column, for each season of the year do not differ significantly from each other by the Tukey test at 5\% probability. CV (\%): Coefficient of variation.

Independent of the exogenous IBA supplementation, the percentage of shoots throughout the four seasons of the year was reduced for the evaluated species. While summer and autumn cuttings resulted in the highest sprouting rates, during the winter season there was no sprout emission for both species.

Spring and summer were more favorable to the survival of the cuttings. However, only in the spring season there were statistical differences among IBA concentrations. For C. adamantium, $75 \%$ of cuttings were kept alive without auxin supplementation, while in C. pubescens, $59.38 \%$ of cuttings survived when supplemented at the $2000 \mathrm{mg} \mathrm{L}^{-1}$ concentration of IBA, demonstrating that regardless of the species, spring was the most appropriate time of the year for cuttings survival.

It was observed a high mortality of $C$. adamantium and $C$. pubescens cuttings. As the concentrations of IBA increased, the percentage of dead cuttings also increased. The high percentage of dead cuttings may have occurred due to the high temperatures recorded, shown in Table 2, besides the phytotoxic effect due to the high auxin concentrations.

The IBA supplementation in the spring and summer seasons resulted in a higher percentage of callus cuttings for C. adamantium and $C$. pubescens at different concentrations. During the winter season there was no calogenesis for C. adamantium.

The percentage of rooted cuttings showed that there were no rhizogenesis in the different seasons of the year for C. adamantium and C. pubescens when treated in different concentrations of IBA.

\section{Discussion}

Shoots percentage is related to the plant early development and it is fundamental on the vegetative propagation process, playing a key role in the formation of the root system, since shoots result in new leaves, which produces 
photoassimilative structures and substances such as auxin, responsible for the rhizogenesis induction (Furlani, Corrêa, Junior, Pereira, \& Paixão, 2018).

Shoots development depends on the apical dominance breakdown from the decapitation of part of the caulinar apex of the cuttings, where stimuli that alter the apex gradient occur, causing, by means of physiological processes, modifications that will interrupt the inhibitions and promote the development of the lateral gems (Ramos, Bakke, Lucena, Borges, \& Sousa Neto, 2016). Shoots emission were also observed in the autumn, in detriment of the other seasons of the year for the species of gabirobeira, C. adamantium and C. pubescens (Pereira et al., 2017) and for C. adamantium (Martins et al., 2015).

According to Pizzatto et al. (2011), the propagules collection season has a strong influence on the growth and development aspects, due to the changes in the biochemical state of the matrix plant from which the cuttings are obtained, which undergo changes in the exchange rate activity due to seasonal variations, with endogenous and nutritional levels altered, which reflects in the final results of the stem cuttings process.

During the winter, shoots absence can be justified by tissues lower metabolic activity, a period of shorter days, which has its physiological processes modified, with negative effect on translocation and photosynthesis, not corresponding to the stimuli due to the vegetative rest form meristems protection (Stuepp, Zuffellato-Ribas, Wendling, Koehler, \& Bona, 2015).

During spring and summer times there are active growth points in the matrix plants, which helps auxin and other cofactors synthesis, resulting in the differentiation of tissues because it's a period of higher vegetative growth, which, associated with high metabolic activity, favored a higher percentage of cuttings survival (Fragoso, Zuffellato-Ribas, Macanhão, Stuepp, \& Koehler, 2015; Marangon \& Biasi, 2013).

However, contrary results were reported during the autumn season by Pereira et al. (2017), when cuttings were supplemented at a maximum IBA concentration of $3200 \mathrm{mg} \mathrm{L}^{-1}$, and it was obtained a $80.71 \%$ survival for $C$. adamantium and a $100 \%$ survival for $C$. pubescens. These results showed that for the same species, discordant responses can occur due to concentrations and biological material, making it important to define the ideal concentration, and the most favorable time for species propagation, validating the importance of studys related to propagation vegetative by cuttings.

The temperature can be an important factor in cuttings survival, rooting and shooting. For woody species, the ideal range from 15 to $35{ }^{\circ} \mathrm{C}$, but it is also known that temperatures from 20 and $30{ }^{\circ} \mathrm{C}$ are favorable to propagative process, since they are desirable for avoiding excessive transpiration, water loss and tissue necrosis (Xavier, Wendling, \& Silva, 2013). According to Hussain, Roberto, Colombo, Assis, and Koyama (2017), temperature can be related with metabolic activities in cuttings tissues. High temperatures causes reducing enzymatic activity or enzymes denaturation (Salmi \& Hesami, 2016). In the present study, the temperatures recorded were above ideal, contributing to reserves exhaustion and to the reduction of cuttings survival in different IBA concentrations.

Besides the changes in the metabolism process and in the solutes distribution, plants undergo to alteration along the branches, thus, due to the high IBA supplementation, there was phytotoxicity reponses in tissues, which led to the exhaustion of reserves and death the most of the cuttings observed. According to Buzzello, Trezzi, Bittencourt, Patel, and Junior (2017), injury or phytotoxicity depends on the species degree of tolerance to the phytoregulator used, suggesting a previous evaluation of phytoregulators in plants of interest, in order to verify the cost-benefit of their use. According to those authors, it is possible to infer that the two species of gabirobeira in the present study suffered injury due to the IBA concentrations, which may blocked the cuttings rooting process besides the effects of high temperatures that were observed (Table 2).

Callus observed in the cuttings are mass of cells with disordered growth that can be varied in shape and size due to their degree of differentiation, according to Ikeuchi, Sugimoto, and Iwase (2013). This occurs in plant tissues because they have a high plasticity, being capable of suffering differentiation.

For Fragoso, Stuepp, Rickli, Zufellato-Ribas, and Koehler (2017b), callus may be precursors of adventitious root formation in certain species, but in other species the mechanism of formation of this structure may be independent, which does not lead to the emergence roots.

Pereira et al. (2017) did not observe calogenesis in the cuttings of C. adamantium and C. pubescens demonstrating the variability for the same species. According to the observed data, callus formation in both species demonstrated tissue competence for the dedifferentiation process, although insufficient for root induction. 
Auxin supplementation at certain concentrations may or may not favor rooting of cuttings, especially in the Myrtaceae family, which the rhizogenes process is considered more complex. In addition, the emergence of shoots may have led to the absence of response to root induction because they function as a drain (Véras, Mendonça, Ramires, Silva, \& Pereira, 2017).

Considering collection seasons and cuttings nutritional conditions, IBA may not result in rooting for all species. Zem et al. (2015) did not find influence on the rooting process of Drymis brasilienses (Winteracea) given the application of different concentrations of IBA when they were cultivated in the four seasons. Similarly, the effect of different concentrations of IBA was not observed by Stuepp et al. (2013) on the propagation of Melaleuca alternifolia.

Silva, Antunes, Roveda, Carvalho, and Biasi (2012), reported that in Cerrado species that were not domesticated, great genetic variability was observed in size, color and nutritional reserves. This behavior observed for native species may explain the high coefficient of variation (CV\%) verified for C. adamantium and C. pubescens for sprouting and percentage of calluses. Such variation is expected in agronomic experiments carried out with non-domesticated species, with not standared biological material, even if the management and cultivation conditions have been controlled.

The collection season of propagules did not influence the root emission of the C. adamantium and C. pubescens, even with the exogenous IBA supplementation and the occurrence of seasonal changes during the phenological phases of plants. On the other hand, Emer, Schaffer, and Fior (2018), evaluating cuttings of Campomanesia aurea in different seasons of the year supplemented with IBA, verified better results in the spring season, when compared to the rooting in the autumn and winter seasons, proving the existence of seasons influence in the vegetative propagation.

According to Wendling, Trueman, and Xavier (2014), the maturation in woody species reduce the regenerative capacity, reflecting at capacity and vigor of rooting, being necessary use juvenile materials, due in some woody species the formation of roots is associated with a maturation gradient, thus, the basal cuttings may be more lignified and apical cuttings less lignified. The lignification of the cuttings reflects in less quantity of meristematic cells, with less active metabolism, which associated with the presence of phenolic compounds, justifies the absence of rooting (Stuepp, Zuffellato-Ribas, Macanhão, Fragoso, \& Rickli, 2014; Rosa, Zanandrea, Mayer, \& Bianchi, 2017).

As expected, it was found that in both seasons there was no adventitial rhizogenesis. It was understood that there is a more complex mechanism cuttings obtained in the different seasons and that is a important point to be elucidated.

\section{Conclusion}

The use of IBA did not promote adventitious rhizogenesis, nevertheless provided a high percentage of survival for the species Campomanesia adamantium and Campomanesia pubescens by stem cutting during spring season.

\section{References}

Alves, A. M., Alves, M. S. O, Fernandes, T. D. O., Naves, R. V., \& Naves, M. M. V. (2013). Physical and chemical characterization, total phenolics and antioxidant activity of the gabiroba pulp and residue. Revista Brasileira de Fruticultura, 35(3), 837-844. https://doi.org/10.1590/S0100-29452013000300021

Buzzello, G. L., Trezzi, M. M., Bittencourt, H. V., Patel, F., \& Miotto Junior, E. (2017) Desenvolvimento e rendimento de soja em função da aplicação de ácido indol-butírico, ácido giberélico e cinetina. Agrarian, 10(37), 225-233. https://doi.org/10.30612/agrarian.v10i37.3584

Emer, A. A., Schafer, G., \& Fior, C. S. (2018). Cutting from Campomanesia aurea O. Berg (Myrtaceae): The collection time of propagules and the effects of auxin. Revista Brasileira de Ciências Agrárias (Agrária), 13(1), 54-94. https://doi.org/0.5039/agraria.v13i1a5494

Ferreira, D. F. (2011). Sisvar: A computer statistical analysis system. Ciência e Agrotecnologia, 35, 1039-1042. https://doi.org/10.1590/S1413-70542011000600001

Furlani, R. C. M., de Souza Corrêa, L., Junior, E. F., Pereira, G. A., \& Paixão, A. P. (2018). Enraizamento de diferentes tipos de estacas de pinhão manso em dois substratos. Cultura Agronômica: Revista de Ciências Agronomicas, 27(4), 450-462. http://dx.doi.org/10.32929/2446-8355.2018v27n4p450-462

Fragoso, R. O., Zuffellato-Ribas, K. C., Macanhão, G., Stuepp, C. A., \& Koehler, H. S. (2015). Vegetative propagation of Juniperus chinensis. Comunicata Scientiae, 6(3), 307-316. https://doi.org/10.14295/ cs.v6i3.825 
Fragoso, R. D. O., Stuepp, C. A., Sá, F. P. D., Kratz, D., Zuffellato-Ribas, K. C., \& Wendling, I. (2017a). Vegetative rescue and ex vitro system production of Tibouchina sellowiana clonal plants by cutting and mini-cutting. Ciência Rural, 47(11). https://doi.org/10.1590/0103-8478cr20160098

Fragoso, R. D. O., Stuepp, C. A., Rickli, H. C., Zuffellato-Ribas, K. C., \& Koehler, H. S. (2017b). Maximum efficiency concentration of indole butyric acid in promoting the rooting of Japanese Flowering Cherry. Ciência Rural, 47(1). https://doi.org/10.1590/0103-8478cr20150894

Gilani, S. A. Q., Shah, K., Ahmed, I., Basit, A., Sajid, M., Bano, A. S., ... Shahid, U. (2018). Influence of indole butyric acid (IBA) concentrations on air layerage in guava (Psidium guajava L.) cv. Sufeda. Pure and Applied Biology, 7(4), 1-8. https://doi.org/10.19045/bspab.2018.700194

Hussain, I., Roberto, S. R., Colombo, R. C., Assis, A., \& Koyama, R. (2017). Cutting types collected at different seasons on blackberry multiplication. Revista Brasileira de Fruticultura, 39(3). https://doi.org/10.1590/ 0100-29452017939

Hossel, C., de Oliveira Hossel, J. S. A., \& Júnior, A. W. (2017). Tamanho de estaca e concentração de ácido indolbutírico na propagação do sabugueiro por estaquia. Revista Brasileira de Tecnologia Agropecuária, $1(2), 109-112$.

Ikeuchi, M., Sugimoto, K., \& Iwase, A. (2013). Plant callus: Mechanisms of induction and repression. The Plant Cell, 25(9), 3159-3173. https://doi.org/10.1105/tpc.113.116053

Marangon, M. A., \& Biasi, L. A. (2013). Estaquia de mirtilo nas estações do ano com ácido indolbutírico e aquecimento do substrato. Pesquisa Agropecuária Brasileira, 48(1), 25-32. https://doi.org/10.1590/ S0100-204X2013000100004

Martins, W. A., Mantelli, M., Santos, S. C., Netto, A. P., \& Pinto, F. (2015). Estaquia e concentração de reguladores vegetais no enraizamento de Campomanesia adamantium. Revista de Ciências Agrárias, 38(1), 58-64.

Mendonça, L. P., Batista, J. N., Magalhães, W. B., Ferreira, J. P., \& Bucher, C. A. (2018). Ácido-indol-3-butirico e época de coleta influenciando no enraizamento de Odontonema strictum (Nees) O. Kuntze. Revista Brasileira de Engenharia de Biossistemas, 12(2), 176-184. https://doi.org/10.18011/bioeng2018v12 n2p176-184

Pereira, L. D., Costa, M. L., Pinto, J. F. N., da Assunção, H. F., dos Reis, E. F., \& da Silva, D. F. P. (2017). Propagação de gabirobeiras via estaquia associada ao ácido indolbutírico. Revista Brasileira de Agropecuária Sustentável, 7(1), 19-25. https://doi.org/10.21206/rbas.v7i1.372

Pizzatto, M., Júnior, A. W., Luckmann, D., Pirola, K., Cassol, D. A., \& Mazaro, S. M. (2011). Influência do uso de AIB, época de coleta e tamanho de estaca na propagação vegetativa de hibisco por estaquia. Ceres, $58(4)$. https://doi.org/10.1590/S0034-737X2011000400013

Ramos, T. M., Bakke, I. A., de Lucena, E. O., Borges, L. D., \& de Sousa Neto, O. M. (2016). Propagação vegetativa de Ipomoea carnea Jacq pelo método de estaquia. Agropecuária Científica no Semiárido, 12(4), 397-402.

Rosa, G. G., Zanandrea, I., Mayer, N. A., \& Bianchi, V. J. (2017). Propagação de porta-enxerto de Prunus spp. por estaquia: Efeito do genótipo, do estádio de desenvolvimento do ramo e tipo de estaca. Ceres, 64(1), 090-097.

Salmi, M. S., \& Hesami, M. (2016). Time of collection, cutting ages, auxin types and concentrations influence rooting Ficus religiosa L. stem cuttings. Journal of Applied Environmental and Biological Sciences, 6(1), 124-132.

Santos, E. A., dos Reis, E. F., Pinto, J. F. N., \& da Silva, D. F. P. (2018). Genetic variability among genotypes of "gabirobeiras" selected for precocity. Cientifica, 46(2), 156-163. https://doi.org/10.15361/1984-5529.2018 v46n2p156-163

Silva, R. C., Antunes, M., Roveda, L., Carvalho, T., \& Biasi, L. (2012). Enraizamento de estacas de Melaleuca alternifolia submetidas a diferentes reguladores vegetais. Semina: Ciências Agrárias, 33(5), 1643-1652. https://doi.org/10.5433/1679-0359.2012v33n5p1643

Stuepp, C. A., Pereira, G. P., Zem, L. M., Peña, M. L., Bueno, P. M. C., Spader, V., \& Rosa, G. M. (2013). Enraizamento de melaleuca: Influência da altura de coleta das estacas e aplicação de IBA. Colloquium Agrariae, 9(1), 01-09. https://doi.org/10.5747/ca.2013.v09.n1.a083 
Stuepp, C. A., Zuffellato-Ribas, K. C., Macanhão, G., de Oliveira Fragoso, R., \& Rickli, H. C. (2014). Enraizamento de estacas de Juniperus chinensis var. kaizuka em função de diferentes concentrações de IBA e alturas de coleta. Agrarian, 7(26), 496-503.

Stuepp, C. A., Zuffellato-Ribas, K. C., Wendling, I., Koehler, H. S., \& Bona, C. (2015). Leaf presence and indolebutyric acid on cuttings rooting of dragon tree. Comunicata Scientiae, 6(2), 181-193.

Véras, M. L. M., Mendonça, R. M. N., Ramires, C. M. C., Silva, S. D. M., \& Pereira, W. E. (2017). Effect of ethephon and indolebutyric acid on yellow mombin propagation via cutting. Pesquisa Agropecuária Tropical, 47(4), 416-423. https://doi.org/10.1590/1983-40632017v4749515

Véras, M., Leno, M., Nunes Mendonça, R. M., Ferreira de Figueredo, L., Araújo, V. L., de Melo Filho, J. S., \& Pereira, W. E. (2018). Enraizamento de estacas de umbuzeiro potencializado pela aplicação de ácido indol-3-butírico (AIB). Brazilian Journal of Agricultural Sciences, 13(3). https://doi.org/10.5039/ agraria.v13i3a5541

Wendling, I., Trueman, S. J., \& Xavier, A. (2014). Maturation and related aspects in clonal forestry-Part I: Concepts, regulation and consequences of phase change. New Forests, 1, 1-23. https://doi.org/10.1007/ s11056-014-9421-0

Xavier, A., Wendling, I., \& Silva, R. L. (2013). Silvicultura clonal: Princípios e técnicas (2nd ed., p. 279). Viçosa, MG

Zem, L. M., Weiser, A. H., Zuffellato-Ribas, K. C., \& Radomski, M. I. (2015). Estaquia caulinar herbácea e semilenhosa de Drimys brasiliensis. Revista Ciência Agronômica, 46(2), 396-403.

\section{Copyrights}

Copyright for this article is retained by the author(s), with first publication rights granted to the journal.

This is an open-access article distributed under the terms and conditions of the Creative Commons Attribution license (http://creativecommons.org/licenses/by/4.0/). 